\title{
THE ENVIRONMENTAL MANAGEMENT APPLICATION ON BUSINESS PERFORMANCE
}

\author{
Ingrid Panjaitan
}

Department of Accounting, Faculty of Economy and Business, Catur Insan Cendekia University, Indonesia

Correspondence Author: Ingrid Panjaitan, Department of Accounting, Faculty of Economic and Business, Catur Insan Cendekia, Indonesia.

Jl. Kesambi No.202, Cirebon City, West Java, Indonesia, Zip Code: 45134

http://dx.doi.org/10.38193/IJRCMS.2021.3308

\begin{abstract}
The environmental degradation around us, especially nowadays, is increasingly felt, the role of companies as actors in the production process that exploits natural and natural resources is very large. Therefore, to suppress the worsening of environmental degradation, companies are required to carry out activities that are not only for profit. Solely, but pays more attention to the survival, nature preservation and socioeconomic of the communities around the company where the company operates through a principle of social responsibility. This study aims to provide empirical evidence regarding the effect of environmental management on business performance with environmental performance as a moderating manufacturing company in the food and beverage industry sub-sector. The population in this study is manufacturing companies subsector of the food and beverage industry listed on the Indonesia Stock Exchange website in 2011 - 2020. The sampling technique in this study was carried out using the purpose sampling technique. Data analysis in this research was carried out with the help of stata software program. A new finding in this study is that the existence of environmental management carried out by companies does not actually affect business performance in the Indonesian sample. But the moderation of environmental performance that has been achieved by the company from the results of environmental management carried out can improve the company's business performance. Industrial activity does not only produce products of sale value. During the production process, waste is also generated. Not a few of these wastes fall into the category of hazardous waste. If this kind of waste is disposed of immediately without being treated in a sewage treatment plant, the waste will pollute the environment. Unfortunately, not a few companies deliberately ignore waste management regulations. Many of them prefer to dispose of hazardous waste for reasons of cost savings. Yet if this is done, the company will also suffer losses. The following sanctions also await.
\end{abstract}

KEYWORDS: Environmental management, business performance, environmental performance 


\section{INTRODUCTION}

The level of competitiveness in the business world is fast and successful in the business environment, the strategy is a key part of the achievement of the superiority of the business and the success of the business. The effort to achieve business strategies can provide a great result for achieving corporate performance. Business performance is needed and important in business competition. Business performance is an activity that begins with performance planning, performance review, and performance assessment. The number of activities that need to be continued in business continues to be competitive. Success or not the strategy and behavior that was struck by the company in the days of the company (Permana and Hariyanti, 2016). The level of acquisition is the loss of the company, which is a measure that is often used to assess the performance of a company. Even though the value is high, the efficiency of the industry will increase so that the profit will be increased even more (Erlinda and Wardhani, 2008).

In this global and established environment to enhance the performance of the company business, it must be carried out by all the companies involved in the move amid the industrial sector (GrossGolacka et al., 2020). The industrial sector has a large role in driving economic growth in Indonesia because of the ability to create high-grade values (Permana and Hariyanti, 2016). With the amount of work done in 2012 around 14 million people (including micro, small, and middle industries), of course, the industrial sector's work contributed $12-13 \%$ to the total work of the industrial sector (Kementerian Perindustrian dan Perdagangan, 2013). The industrial sector has played a big role in the economic development in Indonesia and the manufacturing sector is still poor. Indonesia has a great potential for growth in the manufacturing sector, which is a wide range of products including food and beverage (Permana and Hariyanti, 2016).

As the population growth in Indonesia grows, the volume of need for food and beverage continues to increase. Food and beverage is a human need, it is very important because it is directly related to the existence of human life itself. Seeing the potential of the industrial sub-sector food and beverage in Indonesia that is so large, in this research, the authors chose the sub-sector food and beverage for research because according to the Research Center for Statistics (BPS) several years ago the development of the business sub-sector food and beverage to experience a positive trend. In addition to having positive growth, industrial food and beverage will be an industry that is absorbing a lot of work in Indonesia compared to other industries.

In figure 1 the value of the industrial food and beverage show a trend that is increasing from 2014 to 2018. In 2014, the value of the industrial food and beverage up to 117 trillion rupiahs, and in 2018 has risen and reached 165 trillion rupiahs. The reason researchers chose the food and beverage sub-sector as a study was that the growth in value in the food and beverage sub-sector was more stable due to being driven by sales volume and not affected by economic conditions (Rusdiyanto and Marsa, 2020). 
The high growth potential of the food and beverage industry makes many people get involved in the industry which makes competition in the food and beverage industry more stringent (Susanto, 2017). Permana and Hariyanti (2016) states that the companies in this industry must be able to compete to survive with other companies that are already in the market and potential companies that may enter the industrial market. Moreover, the company in the country was also able to compete with Indonesian products food and beverage imported from outside the country.

More and more who jumped into this industry would certainly be a threat or problem with the company's environmental impact that will occur. Therefore, a company needs the right strategy to overcome the problem of the impacts caused. Agustia et al., (2019) said that the application of the business strategy of the company about the environment needed an important concept that supports the development of environmental plans and helps stakeholder to obtain information. Environmental Management Accounting (EMA) is a concept that helps companies to expand business in the form of monetary units (Agustia et al., 2019). Implementing EMA helps the company in the environment problem record all production activities to be reported in the company's environmental cost report. Research Hasan dan Ali (2015) states that there are some benefits to be gained from implementing environmental management, namely improving the company's image, reduce waste generated by the company, minimize costs, increase customer satisfaction, increase productivity, better goodwill, increase market share, and profitability.

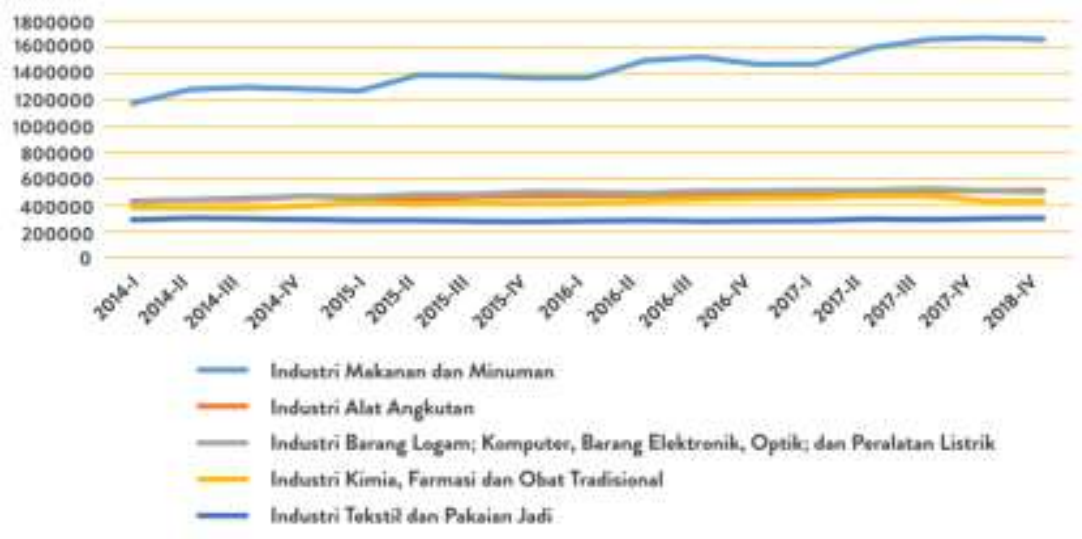

Fig. 1: Growth of Industry Food and Beverage in Indonesia, 2019

In Indonesia, the conflict about the environment is an issue that is still being discussed. According to Ferreira et al., (2010), there are various related issues to the environment such as globalization, ecoefficiency, and the industry's activities which gives a direct impact on the surrounding environment that has created changes in the environment of the company both internally and externally. The 
company did not only has limited responsibility for maximizing profits and provide goods and services but unfortunately, the environmental changes that have occurred are not released from the operational activities carried out by the company. In fact, in terms of the company's environment in Indonesia ensuring the business environment must maintain business processes so that the company can implement business strategies accordingly, improve performance, and gain a competitive advantage for the sake of achieving going concern and sustainable development.

Smith (2011) and R Abdullah et al., (2019) states the environmental performance is the performance of the company to create a good environment within the scope of the company. While according to Pflieger et al., (2005) that the performance of the environment is affected by several agencies that encourage the management of the environment which is carried out by a variety of specialized institutions. Concern over the environment also becomes a concern for stakeholders. The stakeholder pressure makes the company more vulnerable in the environment in minimizing the negative impact of the company on the environment. Unfortunately, some research in Indonesia Nainggolan \& Handoyo (2019); Irfansyah et al., (2018); Arafat et al., (2014) much use the factor to measure the performance of the corporate environment, such as obtaining a PROPER rating. Research Voinea et al., (2020) and Carrillo-Labella et al., (2020) that uses the same factors such as ISO 14000 certification as an indicator of environmental management systems. In this case, only research will only see the effect of the output factor in measuring environmental performance and environmental management.

The environmental performance will also be achieved at high levels if the company itself continues to change to a greater extent and the environmental performance of the company that performs a variety of actions of environmental management is controlled. This research wants to answer some research questions, which is the first question the effects of environmental management on business performance, both of which influence the performance of the environment on business performance, and the three business environments.

\section{LITERATURE REVIEW AND HYPOTHESES DEVELOPMENT}

A stakeholder is all parties, internal or external which can affect or be affected by the company's success or failure both directly and indirectly. Stakeholder consists of the government, competitors, local society, industry, suppliers, investors, environmental agencies, corporate workers of minority groups and so forth the existence of which is influence or is influenced by the company. According to the study of Berry et al., (1998), one of the reasons for a company to take environmental management actions is stakeholders. Stakeholders as the party affected by the company's operations are entitled to get their rights as a stakeholder. Stakeholders want to encourage companies to obey the rules and be more responsible socially and environmentally friendly. According to the study of Andriana and Panggabean (2017) in the past, stakeholder views the company as a provider of goods and services only views companies as providers of goods and services, providers of jobs, providers of 
community welfare. The company not an entity that operates only for its own sake but it also has been able to provide benefits to stakeholders. The existence of a company very much depends on the amount of support provided by the company stakeholder.

Theory stakeholder states that companies are not separated from the social environment around them. Therefore, the company needs to maintain relationships with stakeholders and consider what is desired in making decisions and making policies so the company achieves its goal is stability and going concerned (Olaniyan et al., 2021). Environmental performance very strong with stakeholder theory because the company's activities that are disclosed are very valuable for stakeholders. With the disclosure, stakeholder knows the performance of the company (Derila et al., 2020). Theory stakeholder is considered as a theory which is the foundation of this research because it has an influence on many parties who is a stakeholder of the company.

\section{The Influence of Environmental Management on Business Performance}

Along with increasing environmental awareness circumstances related to the environment becomes even strict so the business must spend investment that is ever greater to help these interests. According to Chaundry, et al., (2020) increased attention and awareness about environmental issues have prompted organizations to use accounting for environmental management. Definition EMA of (International Federation of Accountans) and UNDSD (United Nations Division for Sustainable Development) is environmental management and finance through the implementation of the system and proper accounting practices by identifying, collecting, measuring, calculating, classifying and analyzing environmental (physical and monetary) information to support the acquisition of internal and external decisions (Sofyan and Augustine, 2019).

Corporate social responsibility is a form of responsibility carried out by the company to fix social inequality and environmental damage to the activities of the operations of the company. Even though many responsibilities were carried out by the company to the environment than the better corporate images according to the people. According to Issa (2017) investors are more interested in the company that has a good image in society because if the better image company, the higher the customer loyalty. With increasing consumer loyalty in a long time then the company's sales will improve and the expected level of profitability of the company high. So, the higher the level of profitability of the company, the greater disclosure of social information company (Kusumadilaga, 2010). Disclosure of information is a necessity for stakeholders. Therefore, one form of corporate responsibility towards the environment invites stakeholders to invest, so it will cause benefit to the company. Thus, such a strategy would affect the response positively by investors through stock price fluctuations of companies. The company's stock price relative in the industry concerned is a reflection of the achievement of the economic performance of the company (Irfansyah et al., 2018). 
According to the results of research Irfansyah et al., (2018) find the presence that the Disclosure Environment and the variables that determined previously such Income was Not Unexpected, Environmental Pre-disclosure, Growth Opportunities, Profit Margin, Environmental Concern, and Public Visibility is not a significant variable that determines the economic performance of the. Supported with the results of the research Iredele and Ogunleye (2018) that the company has not fully implemented a Management Accounting Environment. The results of the research Buana and Nuzula (2019) prove environmental management partially and simultaneously does not have a significant effect on profitability which is measured by the ratio. Results of the study Teles and de Sousa (2014) also proved that environmental management has a negative coefficient which is significant. Different from the results of the research Al-Mawali et al., (2018) the use of EMA had a positive relationship between EMA and the performance of the organization. Then the first hypothesis proposed in this research is the management of the environment and a significant positive effect on business performance.

\section{The Influence of Environmental Performance on Business Performance}

Environmental performance according to Kolade et al., (2014) is a mechanism for companies to voluntarily integrate attention to the environment in their operations and interaction with stakeholders. The greater part of the company in environmental activities, the better the company image in the eyes of stakeholders. The better the assessment of the stakeholders, the corporate objectives will be achieved by themselves and the business will run in the expected target. The presence of a positive image will be able to attract the attention of stakeholders and the community of users of financial statements (Haholongan, 2016). The impact is the market will respond in a positive through the fluctuations in stock prices are followed by the rising stock return of companies which on a relative basis is a reflection of the achievement of economic performance. A continuing effort is done in businesses to ensure the sustainability of their business. Action sustainability is seen as a positive action where the action creates positive values for the reputation of the company (Panjaitan, 2017). So, the competition of the businesses drives to always achieve the business performance that is expected (Muis, 2020).

Based on the results of research R Abdullah et al., (2019) show that environmental performance does not affect financial performance. Thus, it is proved that the company is not fully responsible for carrying out its business activities. Different with the results of the research Manrique and MartíBallester (2017); Purnomo and Widianingsih (2012); Zhang et al., (2020), show that the adoption of environmental practices significantly and positively affects the financial performance of the company in developed and developing countries. Research Haholongan (2016) show the results that environmental performance significantly influences the economic performance of the company, it will certainly be easier for investors to assess the performance of the company. Based on the previous research and arguments prepared then it can be proposed the second hypothesis is environmental 
performance has a positive and significant effect on the performance of the business.

The performance of the Environment Moderate the Influence of Environmental Management On Business Performance

According to Bassey et al., (2013), the role of the accounting environment in improving environmental performance refers to one role of accounting is as a provider of information for management. With the accounting environment, in particular, accounting environmental management environmental costs are identified, defined, and allocated appropriately to the product or process, thus allowing management to find opportunities for cost savings (IFAC, 2005). The EMA also provides information about the physical flow of materials, energy, and water used and waste and emissions produced, to facilitate management in carrying out environmental management to improve environmental performance (Deegan, 2002). This has been reinforced by the research of Shodiq et al., (2020); Albelda et al., (2007); Henri and Journeault (2010) consistently find a positive influence of accounting environment on the performance of the environment. The influence of management accounting on the environment has an important contribution to sustainable development to achieve the business success of the company. The underlying reason a company should be concerned with environmental issues, many stakeholders both from the internal and external shows the increased importance of the environmental performance of an organization.

Environmental management is becoming important for companies to increase competitive advantage and be able to compete with the stakeholders so that the number of investors interested to invest in the capital of the company (Evan, 2017). According to the results of the study Purbosanjoyo et al., (2019) indicates that the environmental performance, social disclosure of accounting jointly affect the performance of the economy. Results of the study of Arafat et al., (2014); Haninun et al., (2018) Ratri and Dewi (2017) also show that environmental performance and disclosure simultaneously have a significant effect on the financial performance of the company. Environmental performance significantly positive effect on financial performance through the disclosure of corporate social responsibility this indicates the disclosure of corporate social responsibility can mediate the relationship between environmental performance with financial performance.

Based on the arguments that have been submitted previously, be evidence that the application of EMA to provide many benefits for businesses, especially for companies. This research was conducted using a quantitative approach to test the effect of the application of EMA on the performance of the company's business. Furthermore, in practice, the use of EMA has also affected environmental performance. Based on the previous research and arguments prepared then it can be proposed the third hypothesis is the performance of the environment moderate the influence of environmental management on business performance. 


\section{RESEARCH METHODOLOGY}

The population in this research is in the industrial sector of food and beverage in the Indonesian Stock Exchange in 2009-2018. While the sampling in this study uses a purposive sampling technique with criteria and some of the following:

1. Food and beverage sub-sector manufacturing companies listed on the Indonesian stock exchange with audited financial statements for the period 2009-2018.

2. The company that has a financial statement complete every year (annual report).

3. The company discloses the data relating to the research variables and is available in full.

\section{Variable Operational Research}

The dependent variable in this study is the performance of the business. Business performance can be measured by the economic performance because the performance of the company is relatively in the same industry marked by the annual return of the industry concerned (Irfansyah et al., 2018). According to Al-Tuwaijri et al., (2004) the economic performance is expressed in a scale that is calculated.

$$
\frac{\left(P_{1}-P_{0}\right)+D i v}{P_{0}}-M e_{R I}
$$

Where:

$\mathrm{P} 1=$ Stock price end of the year

$\mathrm{P} 0=$ The share price at the beginning of the year

Div $=$ Dividend

MeRI $=$ Median return industry

Return industry is measured from the industry obtained from reports of the Indonesia Stock Exchange.

The independent variable in this research is the management of the environment. In this research, environmental management can 5 be measured by the disclosure of the environment. Environmental disclosures is the disclosure of information related to the environment in the annual report of the company (Suratno et al., 2004).

The disclosure of the environment is one of the factors used to determine the ranking of the CEP of a company's environmental performance (Al-Tuwaijri et al., 2004). 


$$
\begin{aligned}
& \text { Environmental disclosure }=\int(\text { environmental performance }+ \text { predeterminated variable }) \int \\
& \qquad \mathrm{EnD}=\beta 0+\beta 1 \mathrm{EnP}_{\mathrm{it}}+\beta 2 \mathrm{EnX}_{\mathrm{it}}+\beta 3 \mathrm{Sz}_{\mathrm{it}} \varepsilon 1
\end{aligned}
$$

A moderating variable in this study the environmental performance. Environmental performance is the performance of the company in creating a good environment (green).

$$
\begin{aligned}
& \text { Environmental performance }=\int(\text { economic performance }+ \text { predeterminated variable }) \int \\
& \qquad \mathrm{EnP}=\beta 0+\beta 1 \mathrm{EcPit}+\beta 2 \mathrm{PDit}+\beta 3 \mathrm{GOit}+\beta 4 \mathrm{EnXit} \varepsilon 2
\end{aligned}
$$

Descriptions:

$\mathrm{EcP}$ is economic peformance, $\mathrm{PD}$ is pre-disclosure environment who measured by indicators of the Global Reporting Innitiatives (GRI) using the method of the checklist contains those items the disclosure environment, GO is growth opportunities who measured by the ratio of stock market value against the book value of the capital stock as a proxy for growth opportunities of the future. For conditions in Indonesia, this ratio measures the difference between the market valuation on the value of the company and estimates the aggregate value of transactions accounting mandated by the Financial Accounting Standards, EnX is environmental exposure who measured by the proxy industry characteristics of the sample firms according to the level of the industry is likely to generate pollution through the production process of the company, $\mathrm{I}$ is number of sample companies $(1,2,3,4, \ldots 19), \mathrm{T}$ is the period cross sectional $(1,2,3,4), \alpha 0, \beta 0, \gamma 0$ and is intercept, and the last Firm Size measured by calculating Ln=Total Asset

\section{Methods of Data Analysis}

Descriptive statistics seek to provide an overview or description of data derived from a sample, viewed from the average (mean), standard deviation (a measure of the distance of each value against the mean), variance, maximum and minimum. The classical assumption test is used to determine and understand the data, whether it meets the standards of the classical assumption test, namely normal distribution of data or not, and are autocorrelation, multicollinearity, or heteroscedasticity. The normality test aims to determine the regression model variable bugger has a normal distribution. The normality test used in this research uses a significance level of $5 \%$ if p-value $<0.05$ then the data is not distributed normally.

Test of Multicollinearity aims to test in the model regression analysis found the correlation between the independent variables. Testing criteria, if the value of the tolerance $\leq$ of 0.10 or the VIF value $\geq$ 
10 , then their multicollinearity. However, if the value of the tolerance $\geq$ of 0.10 or the VIF value of $\leq$ 10, it does not happen multicollinearity (Ghozali, 2011).

The autocorrelation test aims to test the linear regression model is no correlation between the bully in the previous period. These symptoms cause the consequence that confidence intervals become wider as well as the variance and standard errors will be mean too low. Good Data is the regression that is free from autocorrelation. An approach that is often used to test whether there is autocorrelation is the Durbin-Watson test and the Run test. If the significance value $>0.05$, then there is no autocorrelation in the regression model (Ghozali, 2011).

The heteroscedasticity test aims to test the regression model occurs similar or inequality a variant of the residual of one observation the other. If the variance from residual of one observation to other observations fixed, then called homoscedasticity and if different called heteroscedasticity (Ghozali, 2011). A good regression Model is that homoscedasticity or does not happen heteroscedasticity. Heteroscedasticity test using Test Glejser where when the probability of significance is above $5 \%$ then the regression model does not contain heteroscedasticity.

This study used one dependent variable and one independent variable, to test the hypothesis using the multiple regression analysis tools. The regression aims to test the influence between one variable with other variables. Testing this hypothesis by using Stata software. As for the equation of regression is:

Description:

$$
\mathrm{Y}=\beta 0+\beta 1 \mathrm{X} 1+\beta 2 \mathrm{Z}+\varepsilon
$$

$\mathbf{X} \mathbf{1}$ is environmental management, $\mathbf{Y}$ is business performance, $\mathbf{Z}$ is environmental performance, $\boldsymbol{\beta} \mathbf{0}$ is constanta, $\boldsymbol{\beta 1}, \boldsymbol{\beta 2}, \boldsymbol{\beta 3}$ is coefficient, and $\boldsymbol{\varepsilon}$ is error term

This study used a significance level $(\alpha) 0.05$ or $5 \%$, to test the hypothesis is accepted or rejected, then the testing performed on the variables of research by testing simultaneously through a simultaneous significance test to explain the influence of independent variables on the dependent variable simultaneously. The basic criteria of decision making for acceptance or rejection are as follows:

1. Ha is accepted, if the $\rho$ value $<0.05$.

2. Ha is rejected, if the $\rho$ value $<0.05$.

Further testing of the Coefficient of Determination (R2) aims to measure the influence of independent variables on the dependent variable (Ghozali, 2011).

\section{RESEARCH RESULT}

Descriptive statistical tests used in this study include the mean, minimum, maximum, and standard 
division.

Table 1: Descriptive Statistics

\begin{tabular}{|l|c|c|c|c|c|}
\hline Variable & Obs & Mean & Std.Dev & Min & Max \\
\hline KB & 110 & 1.44 & 5.99 & 0.420 & 4.11 \\
\hline ML & 110 & 1.80 & 5.40 & 2.27 & 6.30 \\
\hline KL & 110 & 1.05 & 4.01 & 2.75 & 6.30 \\
\hline
\end{tabular}

\section{Description:}

KB is business performance measured by the stock price at the beginning and the end of the year, the dividend, and the median return industry. ML is the management of the environment (environmental measured by the EnP (Environmental Performance), EnX (Environmental Exposure), Firm Size. KL is environmental performance measured by the calculation of the EcP (environmental economic), PD (pre-disclosure) taken into account by the GRI (Global Reporting Innitiatives), GO (growth opportunities), EnX (environmental exposure).

Source: Results of Data Processing STATA, 2021

From table 1 the results of the descriptive statistical analysis show the data of the obs in this study, 110 samples. The variable business performance has an average of 1,44 which means that the data indicate the achievement of the business performance of the company while the standard deviation value is 5,99 with the lowest valuecc 0,420 at Tiga Pilar Sejahtera Food Corporation in 2010 and the highest score is 4.11 at Cahaya Kalbar Corporation in 2017.

Variable management environment in this study the lowest value obtained 2,27 owned by Tiga Pilar Sejahtera Food Corporation in 2014 and the highest 6,30 owned by Indofood CBP Sukses Makmur Corporation in 2016. The average environmental management of 1.80 with a standard deviation of reach of 4.01 .

Variable environmental performance has an average of 1,80 while the standard deviation reached 4.01 with the lowest value of 2.75 which is owned by Tiga Pilar Sejahtera Food Corporation in 2018 and the highest value of 6.30 is owned by Indofood CBP Sukses Makmur Corporation in 2016.

The results of the normality test in table 2 show the value of 0,520 . Because the p-value more than 0.05 , it can be concluded that the data residuals are normally distributed. In other words, the regression model is used to meet the assumptions of normality.

Table 2: Results of Normality Test

\begin{tabular}{|l|c|c|}
\hline \multicolumn{1}{|c|}{ Smaller group } & $\mathrm{D}$ & p-value \\
\hline Resid : & 0.1598 & 0.491 \\
\hline Cumulative : & -0.1682 & 0.520 \\
\hline Combined $K-S:$ & 0.1682 & 0.520 \\
\hline
\end{tabular}

Source: results of data processing, STATA, 2021

The results of the multicollinearity in table 3 . show that the value of tolerance less than 0.10 , namely $0.88<0,10$. The results of the VIF also showed no independent variables that overstate the value of 
ISSN 2582-2292

Vol. 3, No. 03 May-June; 2021

VIF. So, it can be concluded that there is no multicollinearity between the independent variables and the dependent variable.

Table 3: Results of Test of Multicollinearity

\begin{tabular}{|l|c|c|}
\hline \multicolumn{1}{|c|}{ Variable } & VIF & 1/VIF \\
\hline Environmental Performance & 1.32 & 0.745820 \\
\hline Environmental Management & 1.32 & 0.745820 \\
\hline Moderation X.Z & 1.19 & 0.828345 \\
\hline Mean VIF & 0.88 & \\
\hline
\end{tabular}

Source: results of data processing, STATA, 2021

Based on table 4 show that the value of prob $>$ f of 0,6120 . This result means that the value of prob > $\mathrm{f}$ is greater than the significance level of 0.05 , then this study there is no autocorrelation or the violation of the assumption of non-autocorrelation and escapes from the classical assumption test autocorrelation.

Table 4: Results of Autocorrelation Test

\begin{tabular}{|c|c|}
\hline \multicolumn{2}{|c|}{$\begin{array}{l}\text { Wooldridge test for autocorrelation in panel data } \\
\text { Ho : no first-order autocorrelation }\end{array}$} \\
\hline $\mathrm{F}(1,10)$ & 0.274 \\
\hline Prob $>F$ & 0.6120 \\
\hline
\end{tabular}

Source: results of data processing, STATA, 2020

Based on table 5 from results of heteroscedasticity test above, the value of the probability of chi 2 of $0,0996>0,05$. So, it can be said in this study there is no heteroscedasticity or passed the test of heteroscedasticity.

\section{Table 5: Results of Heteroscedasticity Test}

\begin{tabular}{|l|r|}
\hline Breusch-Pagan/Cook-weisberg test for heteroskedastisitas \\
H0: Constants variances \\
Variables: fitted values of kinerja bisnisy & 2.71 \\
\hline Chi2(1) & 0.0996 \\
\hline Prob > chi2 &
\end{tabular}

Source: Results of Data Processing, STATA, 2020

Based on table 6 shows the value of the coefficient resulting from the influence of environmental management on business performance is negative by -000001. It is that weakens the relationship of environmental management to business performance. The results show a significant value on the environmental management that is $0,000<0,05$. So, it can be concluded that the variables of environmental management and a significant negative effect on the performance of the business, then the first hypothesis is rejected. It means that the application of environmental management in the 
company manufacturing subsector food and beverages the period 2009-2018 by using the measurement of environmental disclosure based on the indicators of the Global Reporting Innitiatives (GRI), the company has not fully provided information that is sufficient and complete related activities and its influence on the social condition of the community and the environment in the company-the company. This is due to the implementation of corporate environmental management that requires the environmental cost resulting in a decrease in the business performance of the company.

\section{Table 6: Results of Linear Regression}

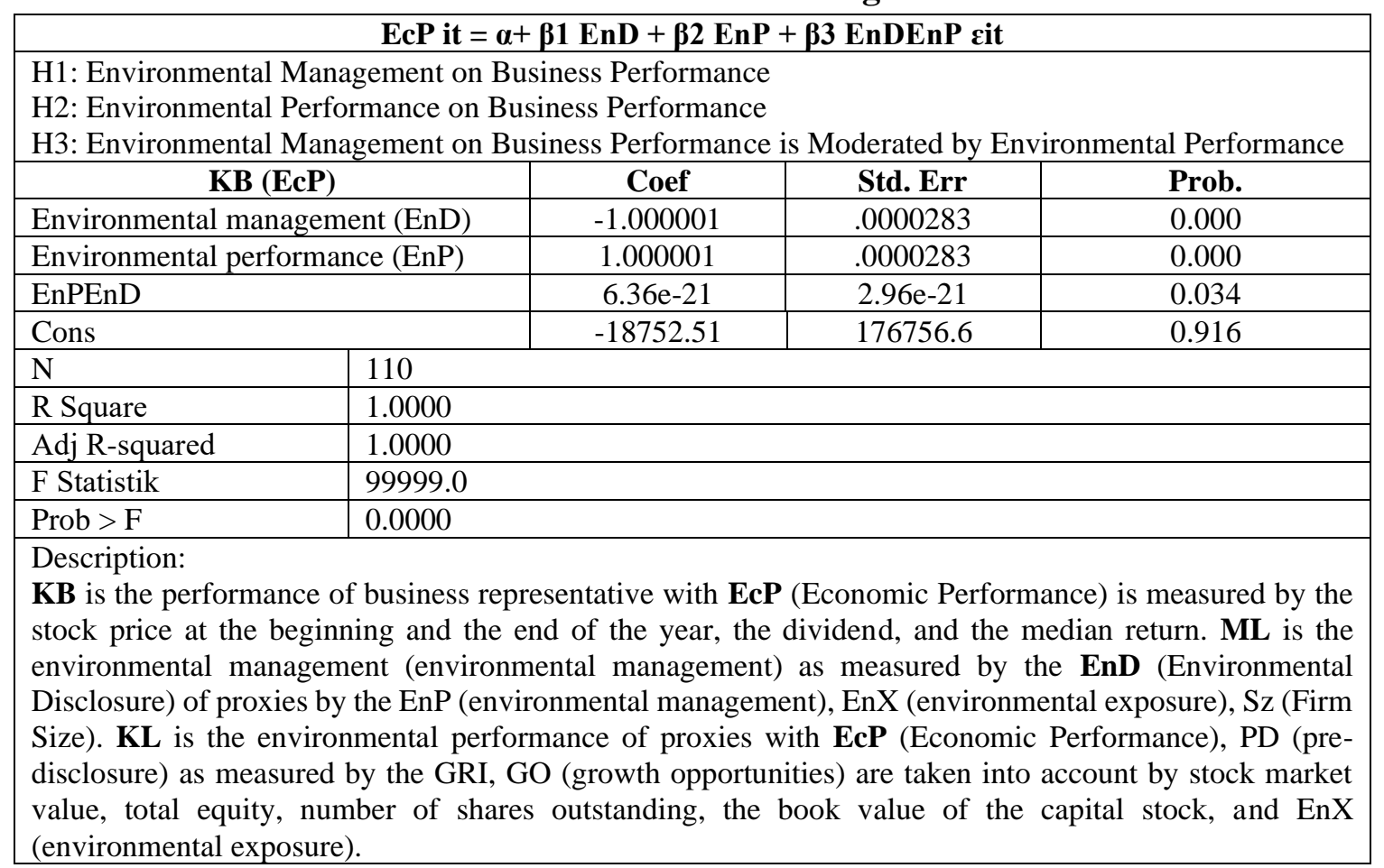

Source: Results of Data Processing, STATA, 2020

This research is in line with Teles and de Sousa (2014) research that has been proved that environmental management has a significant negative coefficient, Chen et al., (2014) show the results of environmental management has a significant negative 8 coefficient, Iredele and Ogunleye (2018) stated that the company has not fully implemented Management Accounting Environment, accountants need to perform environmental studies further to understand its application. This can be done company with a focus on prevention or prevention, thus the company not only improves the environment that has been polluted but also keep and preserve it to achieve the business performance of the company (Supriyadi et al., 2019).

The results of testing the variables of the environmental performance show the value of the positive coefficient that is 1,000001 and a significant value of $0,000<0,05$. It can be concluded that environmental performance has a positive and significant effect on the performance of the business, 
then the second hypothesis is accepted. This research is in line with the results Derila et al., (2020) show that environmental performance has a positive influence and significant impact on economic performance. It means that environmental performance, although in developing countries such as Indonesia, affects financial performance. This indicates the community responds to better environmental performance which is run by the company, thereby increasing the economic activity of the company (Haholongan, 2016). Companies with good environmental performance will get a good response from the investors and stakeholders to have an impact on increasing the revenue of the company in the long term (Camilia, 2016). With this the company has to meet the quality of the business decision, the evaluation was conducted over the entire available information regarding the financial condition, management, plans, and strategies, as well as the business environment of companies he results of this test, are also consistent with research Purnomo and Widianingsih (2012), Zhang et al., (2020), and Haholongan (2016).

The results of testing the moderating variable indicate the value of coefficient positive, of 6.36 , and a significant value that is equal to $0,034<0,05$. It can be concluded that the moderation of environmental performance has a positive and significant effect on the influence of environmental management on the performance of the business, then the third hypothesis is accepted. The environmental performance will be achieved at a high level if companies proactively perform a variety of actions of management of the environment in a controlled manner. With the proactive action of the company in the management of the environment as well as its high performance, the company's management is expected to encourage the growth of good economic performance (Haholongan, 2016). This is supported by the results of the research Damanik and Yadnyana (2017), Haninun et al., (2018), Arafat et al. (2014) show that environmental performance and environmental disclosures significant positive effect on financial performance.

The coefficient of determination ( $\mathrm{R} 2$ square) of the 1.0000 , which means $100 \%$ of the variable environmental management and environmental performance can fully explain business performance. The overall model estimated is significant with Prob F (Stat) equal to 0,0000, which means the model is valid and all independent variables together can influence the dependent variable.

\section{CONCLUSION}

Based on the results of research and discussion that has been done, then the author can conclude, provide advice and input to the parties associated with the management environment, business performance, and environmental performance as follows; environmental Management and a significant negative effect on the performance of the business. This is because companies do not fully provide information that is sufficient and complete related activities and its influence on the social condition of the community and the environment in the company subsector of food and beverage, environmental Performance has a positive and significant effect on the performance of the business. 
This suggests the presence of good performance, good environmental performance will get a good response from the investors and stakeholders also have an impact on increasing the revenue of the company in the long term so that will be achieved the business performance of the company, the Moderation of environmental performance has a positive and significant effect for the influence of environmental management on business performance. It is that the application of environmental management provides many benefits for businesses, especially for companies.

Current research still has many shortcomings and limitations, among them; the disclosure environment in the company is less detailed. Not adjust entirely on what aspects of the guide GRI and annual reports of companies manufacturing subsector food and beverage industry are not all that meet the criteria up to 10 years.

Advice to various stakeholders namely; for investors, this research provides empirical evidence that the level of corporate environmental management is valuable information that deserves consideration as one of the criteria of decision making a rational investment by the investor, for the management of the potential companies that generate hazardous waste and toxic especially food and beverage companies in Indonesia who want to improve the management of the environment in the annual report, the company should first improve its environmental performance. For further research, it is recommended can supplement the limitations of this study, namely; adding the sample of manufacturing companies from other industries are more so the result of the testing is complete, can provide an overview of the research with the same theme as this research or can expand it by adding profitability ratios, and use other variables related to environmental management, as well as using different analytic methods to produce more accurate results.

\section{REFERENCES}

Agustia, Dian., Swarjuwono, Tjiptohadi., and Wiwik, Dianawati. (2019). The Mediating Effect of Environmental Management Accounting on Green Innovation - Firm Value Relationship. International Journal of Energy Economics and Policy,9(2), 299-306. https://dx.doi.org/10.32479/ijeep.7438

Albelda Pérez, E., Correa Ruiz, C., and Carrasco Fenech, F. (2007), "Environmental Management systems as an embedding mechanism: a research note", Accounting, Auditing \& Accountability Journal, 20 (3), 403-422. https://doi.org/10.1108/09513570710748562

Al-Mawali, H., Sharif, A. Al, Rumman, G. A., and Kerzan, F. (2018). Environmental Strategy, Environmental Management Accounting and Organizational Performance: Evidence from The United Arab Emirates Market. Journal of Environmental Accounting and Management, 6(2), 105-114. https://doi.org/10.5890/JEAM.2018.06.002 
Al-Tuwaijri, S. A., Christensen, T. E., and Hughes, K. E. (2004). The relations among environmental disclosure, environmental performance, and economic performance: A simultaneous equations approach. Accounting, Organizations and Society, 29(5-6), 447-471.

Andriana, Abigail., and Panggabean, Rosianta Ria. (2017). The Effect of Good Corporate Governance and Environmental Performance on Financial Performance of the Proper Listed Company on Indonesia Stock Exchange. Binus Business Review, 8(1):1. https://dx.doi.org/10.21512/bbr.v8i1.1757

Arafat, M. Y., Wreck, A., and Dewi, S. R. I. (2014). Does Environmental Performance Really Matter? A Lesson from the Debate of Environmental Disclosure and Firm Performance. Journal of Organizational Management Studies, $\quad$ 2012(September), 15. https://dx.doi.org/10.5171/2012.213910

Buana, Vieni A., and Nila F. Nuzula. Pengaruh Environmental Cost terhadap Profitabilitas dan Nilai Perusahaan (Studi pada Perusahaan Kimia First Section yang Terdaftar di Japan Exchange Group Perode 2013 - 2015). Jurnal Administrasi Bisnis S1 Universitas Brawijaya, 50(1), Sep. 2017, 46-55. Retrived from ttps://www.neliti.com/id/publications/186363/pengaruh-environmentalcost-terhadap-profitabilitas-dan-nilai-perusahaan-studi-p\#cite on 1 April 2021

Bassey, B E.; Effiok, S O., \& Eton, O E. (2013). The Impact of Environmental Accounting anf Reporting on Organizational Performance os Selected Oil and Gas Companies in Niger Delta Region of Nigeria. Research Journal of Finance and Accounting, 4(3), 57-73. Retrived from https://iiste.org/Journals/index.php/RJFA/article/view/4962/5045 on 1April 2021

Carrillo-Labella, R., Fort, F., \& Parras-Rosa, M. (2020). Motives, Barriers and Expected Benefits of ISO 14001 in the Agri-Food Sector. Sustainability, 12(5), 1724. https://dx.doi.org/10.3390/su12051724

Chaudhry, Naveed Iqbal; Asad, Humaira; Amir Ch., Muhammad; Hussain, Rai Imitiaz. (2020). Environmental innovation and financial performance: Mediating role ofenvironmental management accounting and firm's environmental strategy. Pakistan Journal of Commerce and $\begin{array}{lllll}\text { Social Sciences } & \text { (PJCSS), } & 14 & \text { (3), } & \text { 715-737. }\end{array}$ https://www.econstor.eu/bitstream/10419/224961/1/1735158771.pdf on 31 March 2021

Chen, T. T., Honda, T., Hosoda, E., and Hayase, K. (2014). The Relationship between Environmental Management and Economic Performance: A New Model with Accumulated Earnings Ratio, (June), 59-69.

Deegan, C. (2002). Introduction: The legitimising effect of social and environmental disclosures - a theoretical foundation. Accounting, Auditing \& Accountability Journal, 15(3), 282-311. https://dx.doi.org/10.1108/09513570210435852 
Rusdiyanto., \& Narsa, I Made. (2020). The Effect of Company Size, Leverage and Return on Asset on Earnings Management: Case Study Indonesian. Revista Espacios, 41(17), 25-35. Retrived from http://revistaespacios.com/a20v41n17/a20v41n17p25.pdf on 31 March 2021

Ferreira, A., Moulang, C., and Hendro, B. (2010). Environmental management accounting and innovation: an exploratory analysis. Accounting, Auditing \& Accountability Journal, 23(7), 920 948. https://dx.doi.org/10.1108/09513571011080180

Ghozali. (2011). teknik analisis regresi berganda. In Aplikasi Analisis Multivariate dengan Program IBM SPSS 19. Semarang.

Gross-Gołacka, E., Kusterka-Jefmańska, M., and Jefmański, B. (2020). Can Elements of Intellectual Capital Improve Business Sustainability?-The Perspective of Managers of SMEs in Poland. Sustainability, 12(4), 1545. https://dx.doi.org/10.3390/su12041545

Haholongan, R. (2016). Kinerja Lingkungan dan Kinerja Ekonomi Perusahaan Manufaktur Go Public. Jurnal Ekonomi Dan Bisnis, 19(3), 413-424. https://dx.doi.org/10.24914/jeb.v19i3.477

Haninun, N. A., Lindrianasari, N. A., and Denziana, A. (2018). The effect of environmental performance and disclosure on financial performance. International Journal of Trade and Global Markets, 11(1/2), 138-148. https://doi.org/10.1504/IJTGM.2018.092471

Hasan, Z., and Ali, N. A. (2015). The Impact of Green Marketing Strategy on the Firm's Performance in Malaysia. Procedia - Social and Behavioral Sciences, 172, 463-470. https://dx.doi.org/10.1016/J.SBSPRO.2015.01.382

Henri, J. F., and Journeault, M. (2010). Eco-control: The influence of management control systems on environmental and economic performance. Accounting, Organizations and Society, 35(1),63-80. https://dx.doi.org/10.1016/j.aos.2009.02.001

Iredele, Oluwamayowa. (2018). An Evaluation Of Environmental Management Accounting (Ema) Practices And Barriers To Its Implementation: A Comparative Study Of Nigeria And South Africa. Crawford Journal of Business \& Social Sciences, 13 (1). 96-113. Retrived from https://cjbasscru.org/wp-content/uploads/2019/02/AN-EVALUATION-OFENVIRONMENTAL-MANAGEMENT.pdf on 1April 2021

Irfansyah., Ermaya, Husnah., \& Septyan, Krisno. (2018). The Influence Of Environmental Performance, Environmental Disclosure And Environmental Cost On Economic Performance. Economic and Accounting Journal 1(2), 87-94. https://dx.doi.org/10.32493/eaj.v1i2.y2018.p8794

Issa, Ayman I. F. (2017). The Factors Influencing Corporate Social Responsibility Disclosure in the 
Kingdom of Saudi Arabia. Australian Journal of Basic and Applied Sciences, 11(10), 1-19. Retrived from https://philarchive.org/archive/ISSTFIv1 on 31 March 2021

Shodiq, Muhammad Jafar., Fauzi, Hasan., and Ghozali, I. (2020). The Influence of Management Control System, Encouragement of Environmental Management, and Proactive Environmental Management on Carbon Emission Efficiency. https://dx.doi.org/10.2991/aebmr.k.200127.032.

Kementerian Perindustrian dan Perdagangan. (2013). Semester I, Konsumsi Plastik 1,9 Juta Ton.

Manrique, S., and Martí-Ballester, C.P. (2017). Analyzing the Effect of Corporate Environmental Performance on Corporate Financial Performance in Developed and Developing Countries. Sustainability, 9(11), 1957. https://dx.doi.org/10.3390/su9111957

Muis, I. (2020). Marketing Strategy and Capability as the Mediators in Relationship of Market Orientation and Export Performance: A Case Study of Rattan Processing SMEs. Binus Business Review, 11(1), 31-42. https://doi.org/10.21512/bbr.v11i1.5964

Nainggolan, Ivan Juni., and Handoyo, Sofik. (2019). The Influence of Corporate Social Responsibility (CSR) Disclosures on Corporate Financial Performance with Industrial Types as Moderating Variables. Journal of Accounting Auditing and Business, 2(1), 64-73. http://dx.doi.org/10.24198/jaab.v2i1.20532

Olaniyan, O.N., Efuntade, A.O., and Efuntade, O.O. (2021). Corporate Social Responsibility and Firm Financial Performance in Nigeria: Mediating on Ethnical Responsibility. Annals of Spiru Haret University. Economic Series, 21(1), 25-47. https:/dx./doi.org/10.26458/2041

Panjaitan, I. (2017). The Influences of Sustainability Report and Corporate Governance toward Financial and Entity Market Performance with Political Visibility as Moderating Variable. Binus Business Review, 8(1), 61-66. https:/dx.doi.org/10.21512/bbr.v8i1.1282

Permana, Yudhistira., and Hariyanti, Dini. (2016). Analysis of Food and Beverage Industry in Indonesia Using Structure, Conduct and Performance (SCP) Paradigm. OIDA International Journal of Sustainable Development, 09(11), 61-72, 20. Retrieved from https://ssrn.com/abstract=2898384 on 1April 2021

Pflieger, J., Fischer, M., Kupfer, T., and Eyerer, P. (2005). The contribution of life cycle assessment to global sustainability reporting of organizations. Management of Environmental Quality: An International Journal.

Purnomo, P. K., \& Widianingsih, L. P. (2012). The Influence of Environmental Performance on Financial Performance with Corporate Social Responsibility (CSR) Disclosure as a Moderating Variable: Evidence from Listed Companies in Indonesia. Review of Integrative Business and 
ISSN 2582-2292

Vol. 3, No. 03 May-June; 2021

Economics Research, $\quad$ 1(1), 57-69. Retrieved from https://buscompress.com/uploads/3/4/9/8/34980536/riber_riber2012-088 57 57-69_.pdf $\begin{array}{lll}\text { on } 1 & 1\end{array}$ April 2021

R, Abdullah., D, Mahmuda., E, Malik., E, T Pratiwi., M, Rais., A, Dja'wa., L O D, Abdullah., Hardin., M, Lampe., and A, P Tjilen. (2019). Evironmental Costs, and Firm Size on Financial Performance With Corporate Social Responsibility As Intervening Variables (Emperical Study on Manufacturing Companies Listed on The Indonesia Stock Exchange 2014-2018). OP Conf. Ser.: Earth Environ. Sci.343 012136

Ratri, R. F., and Dewi, M. (2017). The Effect of Financial Performance and Environmental Performance on Firm Value with Islamic Social Reporting (ISR) Disclosure as Intervening Variable in Companies Listed at Jakarta Islamic Index (JII). SHS Web of Conferences, 34, 12003. https://dx.doi.org/10.1051/shsconf/20173412003

Smith, Stephen. (2011). Evironmental Economics: A Very Short Introduction. Oxford University Press.

Sofyan, Ardi; and Augustine, Yvonne. (2019). The Effect of Competitive Strategy and Good Corporate Governance on Firm Valuewith Investment Opportunity set as aModerating Variable. International Journal of Management and Administrative Sciences (IJMAS), 6 (4), (14-24). Retrieved from https://www.ijmas.org/IJMAS-6501-2019.pdf on 1 April 2021

Supriyadi., Sulistiyo, Agung Budi., and Roziq, Ahmad. (2019) Influence Disclosure of Sustainability Report and Company Size on Devidend Policy and Company Value with Profitability as Intervening Variables. International Journal of Scientific and Technology Research, 8(7), 716721. Retrieved from https://www.ijstr.org/research-paper-publishing.php?month=july on 1 April 2021

Teles, Maria de Fátima. \& de Sousa, Jorge Freire. (2014). Environmental Management and Business Strategy: Structuring the Decision-Making Support in a Public Transport Company, Transportation Research Procedia, 3(July), 155-164. https://doi.org/10.1016/j.trpro.2014.10.101

Voinea, C. L., Hoogenberg, B.-J., Fratostiteanu, C., and Bin Azam Hashmi, H. (2020). The Relation between Environmental Management Systems and Environmental and Financial Performance in Emerging Economies. Sustainability, 12(13), 5309. https://dx.doi.org/10.3390/su12135309

www.idx.co.id

www.forbil.org 
Zhang, Y., Wei, J., Zhu, Y., and George-Ufot, G. (2020). Untangling the relationship between Corporate Environmental Performance and Corporate Financial Performance: The double-edged moderating effects of environmental uncertainty. Journal of Cleaner Production, 263, 121584. https://doi.org/10.1016/j.jclepro.2020.121584

\section{Author Biography}

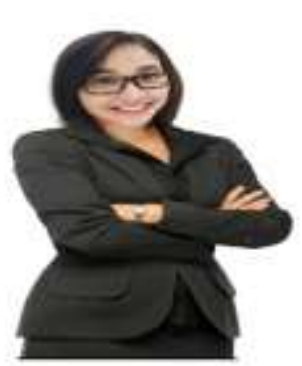

Ingrid Panjaitan is a Dean of Faculty of Economy and Business at Catur Insan Cendekia University, Indonesia. She completed his master degree from Gadjah Mada University Indonesia in 2010. Her research focus is on environmental accounting, sustainability and external corporate responsibility. 